\title{
Maaseudun kehittäminen vaatii monialaista koulutusta
}

\author{
Pirjo Siiskonen
}

\begin{abstract}
Helsingin yliopiston Maaseudun tutkimus- ja koulutuskeskus Mikkelissä on nyt toiminut kolmetoista vuotta. Yksikön tehtävä on kehittää maaseudun elinkeinoja ja elinoloja , lisätä maaseudun elinvoimaa. Kolmentoista vuoden työ on osoittanut, että monet keinot ovat tarpeen. Keskeisimpiä ja tuloksekkaimpia välineitä ovat kuitenkin sellaiset kehittämishankkeet, joissa maaseutuyrittäjät ja maaseudun asukkaat itse ovat mukana sekä sellainen aikuiskoulutus, jossa yhdistetään toimialaosaaminen ja yrittäjyysosaaminen. Tarvitaan myös hyvin pitkälle popularisoituja ja selkokielisiä julkaisuja.
\end{abstract}

$\mathrm{M}^{2}$

aaseutu on mahdollisuuksia täynnä. Aina on kuitenkin kyse kulutuskysynnästä ja siihen vastaamisesta. Kun kehitämme maaseutua, on ensimmäinen kysymys aina: mihin maaseutua tarvitaan. Yhteiskunnan kaupungistumiskehitys etenee tällä hetkellä sellaista vauhtia, että koko maaseudun rooli kansalaisten keskeisten tarpeiden tyydyttäjänä uhkaa unohtua. Siksi maaseudun kehittäjäorganisaatio joutuu koko ajan vahvistamaan niin maaseudun kuin kaupunginkin asukkaiden uskoa siihen, että maaseutua tarvitaan, maaseudulla on mahdollisuuksia ja yhteiskunta tarvitsee sekä kaupunkeja että maaseutua. Maaseudun kehittäjäorganisaatio toimii välittäjän roolissa. Maaseudun kehittäjäorganisaatiolla on oltava tuntosarvet kaikkiin suuntiin ja kykyä toimia yhteistyössä eri toimijoiden kanssa. On tunnettava kulutuskysyntä ja ennakoitava sen trendit oikein, on pystyttävä tiedon tuotteistamiseen ja edelleen siirtoon välittäjille, mutta on myös kyettävä käytännön kehittämistyöhön maaseudun ihmisten kanssa.
Kulutuskysyntätrendit suosivat ekoa ja luomua

$\mathrm{M}$ aaseutu on aina tuottanut ruokaa kansalaisille. Niin kauan kuin yhteiskunnassa oli nälkä, oli oleellista, että maaseutu pystyi tuottamaan riittävän määrän ruokaa. Tämän päivän valistunut kansalainen odottaa, että maaseutu tuottaisi terveysvaikutteisia elintarvikkeita ja turvallista ruokaa. Keski-Euroopan ruokaskandaalit ovat tehneet pr-työtä paikallisen ja kansallisen ruoantuotannon sekä luomuruoan puolesta. Valistunut kansalainen pohtii myös, mikä on terveellistä asumista, miten voisimme hyödyntää metsiemme puuvarantoja rakennusmateriaaleina ja energiana. Kaupungistumiskehitys taas synnyttää vastavaikutuksen ja kaupunkilainen kaipaa maaseutuympäristön ja luonnon tarjoamaa vastakohtaisuutta ja erilaisuutta. Maaseutua tarvitaan kaupunkilaisen vapaa-ajan ympäristönä ja elämysten tuottajana. 


\section{Vastaako maaseutu}

\section{kysyntään?}

$\mathrm{V}$ aikka tiedämme, että kulutuskysyntätrendit ovat esitetynsuuntaisia, ei maaseutu pysty käden käänteessä vastaamaan kysyntään. Vaikka kulutuskyntäkäyrät osoittavat vahvasti luomun suuntaan, ei tuotantokoneistoa voida muutamassa vuodessakaan siirtää luomuun. Vaikka olemme nyt 10 vuoden ajan kouluttaneet luonnonmukaisen maataloustuotannon asiantuntijoita, neuvojia ja opettajia ja viljelijöitä, vasta $6 \%$ maan peltoalasta on luomutuotannossa. Muutos etenee pienten askelten tietä.

Muutosvastarinta maaseudulla on kova. Viljelijäväestö käy henkistä taistelua sen välillä, valitako EU:n suosima voimaperäisen ja yksipuolisen tuotantotavan malli, joka ruoan tuotannon lisäksi tähtää voiton maksimointiin vai eettisesti kestävän luomutuotannon malli, joka vaatii uuden tuotantotavan opettelua, paljon opiskelua ja uskoa siihen, että onnistuu ja että luomu on todellakin se, mitä kuluttajat tulevaisuudessa haluavat. Lisäksi olisi muututtava tuottajasta yrittäjäksi ja käännettävä koko toimintakonsepti ylösalaisin: tuotan sitä, mistä on kysyntää, haluan tuntea asiakkaani ja heidän tarpeensa, pystyn muuttamaan ja kehittämään tuotantoa kulutuskysynnän muutosten mukaan, olen yrittäjä.

Kun sitten on kyse raaka-ainetuotannon lisäksi jalostamisesta, tarvitaan yrittäjyyden oppimisen lisäksi oppia hillonkeitossa, makkaranteossa tai pellettien puristamisessa. Myös toimialaosaamisen on oltava vahvaa.

\section{Tarvitaan maaseudun erityis- olosuhteet tuntevaa koulutusta}

$\mathrm{T}$ yöskentely maaseutuympäristössä asettaa kehittäjille ja kouluttajille omat vaatimuksensa. Työskentelyä saattaa helpottaa se, että tuntee, miten maaseudulla on totuttu ajattelemaan ja toimimaan. On hyvä olla tietoinen siitä, että naapurien yhteistyön este saattaa olla edellisen sukupolven käymä rajariita tai kiista tien paikasta. On myös hyödyksi tietää, että tuottaminen on ollut maaseudulla tuttu toimintatapa pitempään kuin myyminen tai markkinointi. Sukupuolten välinen tasa-arvo saa sekin omat ilmentymänsä maaseutuympäristössä ja sukupolvien kesken vallitsee erilainen kulttuuri ja käytännöt. Maaseudulla toimivan on syytä tuntea toimintaympäristönsä ja sen erityispiirteet..

Ei siis riitä, että opettaa yrittäjyyttä eikä riitä, että opettaa tuotteiden jatkojalostusta. Opettaminen on tuotteistettava kohdejoukolle sopivaksi. Tästä syystä olemme yhteistyössä muiden yliopistojen aikuiskoulutusorganisaatioiden kanssa kehittäneet Maaseutu -PD -koulutusohjelman, joka perehdyttää maaseudun kehittäjän monimuotoiseen toimintaympäristöönsä, sen historiaan ja nykyrakenteisiin, toki myös maaseutupolitiikkaan ja -ohjelmiin sekä käytännön projektityöhön ja sen arviointiin. Ohjelma on ollut tarpeen siksi, että maaseudun toimintaympäristöosaaminen on laiminlyöty yliopiston perusopinnoissa.

\section{Koulutusta eri kohderyhmille}

$\mathrm{M}$ aaseudun kehittäjän monimuotoiseen toimintaympäristön, sen historiaan ja nykyrakenteisiin, toki myös maaseutupolitiikkaan ja -ohjelmiin sekä käytännön projektityöhön ja sen arviointiin. Ohjelma on ollut tarpeen siksi, että maaseudun toimintaympäristöosaaminen on laiminlyöty yliopiston perusopinnoissa.

Maaseudun kehittämistyössä ollaan tekemisissä useiden eri kohdejoukkojen kanssa. Maaseudun keskeisimpiä toimijoita ovat maaseudun asukkaat itse. Kun puhutaan maaseudun asukkaista 
tai maaseutuväestöstä, mielletään helposti, että kyse on vain viljelijöistä. Todellisuudessa maaseudulla asuu runsas miljoona suomalaista, mutta toimivia maatiloja on vain noin 80-90 000 . Jos siis ryhmittelemme maaseudun asukkaita osajoukkoihin, ovat viljelijöiden lisäksi merkittäviä ryhmiä palkansaajat, maaseutuyrittäjät, eläkeläiset, työttömät ja osa-aikaisesti myös loma-asukkaat. Jos siis haluamme kehittää maaseutua, on meidän suunnattava huomiotamme kaikille näille ryhmille: kukin niistä on maaseudun voimavara.

Maaseudun elinkeinotoiminnan ja yrittäjyyden luomisessa koulutuksemme keskeisiä kohderyhmiä ovat olleet viljelijät, maaseutuyrittäjät ja työttömät. Sen sijaan paikalliseen kehittämistyöhön, kuten kylätoimintaan ja POMO- sekä Leader hankkeisiin ovat yhtä lailla ottaneet osaa kaikki maaseudun väestöryhmät.

Ei riitä, että vain me tarjoamme koulutusta maaseudulla asuville. Tarvitaan paljon laajempi ja koko maan kattava neuvoja- ja opettajajoukko. Siksi järjestämme täydennyskoulutusta maaseutuväestön keskuudessa työskenteleville neuvojille, opettajille ja projektityöntekijöille. Esimerkiksi luonnonmukaisen maataloustuotannon osaamisen levittämisessä on ollut oleellista, että koko maan kattavaan neuvontajärjestöön on voitu kouluttaa luomuneuvojaverkosto. Uusien luomuneuvojien opettamisessa taas jo toimivien luomuviljelijöiden toimiminen opettajina on osoittautunut tuloksekkaaksi ratkaisuksi. Kaikenkaikkiaan toisiltaan oppiminen on yksi aikuiskoulutuksen keskeisimpiä metodeja.

\section{Uusimmat koulutustuotteet}

\section{A}

ikuiskoulutusyksikkö keskittyy nimensä muaaisesti aikuiskoulutukseen. Tämä ei kuitenkaan riitä silloin, kun yhteiskunnan peruskoulutusjärjestelmässä on sellaisia aukkoja, että ne paremman yhteiskunnan luomiseksi on syytä pikaisesti paikata. Maaseudun kehittämistyössä olemme löytäneet tällaiset aukot luonnonmukaisen maataloustuotannon ja elintarviketalouden sekä maaseutuopin yliopistollisesta perusopetuksesta. Meillä ei voi yliopistossa valmistua "luomumaisteriksi" eikä "maaseutumaisteriksi". Maaseudun tutkimus- ja koulutuskeskus, Mikkeli on yhteistyössä oman emoyliopiston kanssa lähtenyt korjaamaan tätä epäkohtaa. Luomussa opetuksen kivijalka on yksikön kymmenvuotinen työ luomualan aikuiskoulutuksessa, tutkimuksessa ja oppimateriaalituotannossa. Sivuaineopetusta tuotetaan nyt tavoite 1-ohjelmakauden erillisrahoituksella yhteistyössä maatalous-metsätieteellisen tiedekunnan ja eläinlääketieteellisen tiedekunnan kanssa. Tavoitteena on a-opintokokonaisuuden tarjoaminen näiden tiedekuntien opiskelijoille Mikkelissä tänä syksynä ja copintokokonaisuus kevätlukukaudella 2002. Sitä mukaa kuin opintokokonaisuudet valmistuvat, niitä siirretään myös avoimen yliopiston opetukseen kaikkien alan tietoa janoavien kansalaisten ulottuville.

Vastaavasti aukko löytyy myös Suomen yliopistolaitoksen maaseutuopinnoista. Niitä ei varsinaisesti ole olemassa. Tilanne on tunnistettu myös opetusministeriössä. Tulosneuvotteluissa Helsingin yliopiston kanssa on sovittu, että Mikkelissä aloitetaan yliopistotasoisten maaseutuopintojen verkostomallinen tuotanto. Sivuaineopintokokonaisuuden (a tai c) voisi tässä toimintamallissa liittää osaksi minkä tahansa maamme yliopiston maisteritutkintoa. Tämän jälkeen pyritään siihen, että opiskelija voisi tehdä oman pääaineensa opinnäytetyön maaseutuviitekehyksessä ja halutessaan osana yksikkömme tutkimus- ja kehittämishankkeita.

Samanlainen toimintamalli on suunnitteilla luonnonmukaisen maataloustuotannon ja elintarviketalouden opinnoissa. Opinnäytetutkimukset voivat myös omalta osaltaan olla viemässä eteenpäin niin luonnonmukaisen maa- ja elintarviketalouden kuin maaseudunkin kehitystä erityisesti Etelä-Savossa, mutta laajemmin koko maassa.

Samalla tulee todennettua se, että kehitystyön vaikutussuunta voi kulkea myös aikuiskasvatuksesta perusopetuksen suuntaan eikä ainoastaan päinvastoin. Aikuiskoulutuksen ja kehittämishanketyön piirissä havaittu tiedontarve ja uuden tiedon tuotanto voi generoida kokonaan uusia oppialoja yliopistotasollekin. 